Check for updates

Nuffield Trust, UK

Cite this as: BMJ 2021;374:n1756 http://dx.doi.org/10.1136/bmj.n1756 Published: 12 July 2021

\section{Political appointees in the NHS: be careful what you wish for}

The 2021-22 Health and Care Bill gives politicians powers to control how the healthcare service runs. But past evidence suggests this may be unwise

\section{Nigel Edwards chief executive}

One of the few positives of the health secretary Andrew Lansley's NHS reforms was his determination to remove the secretary of state for health and social care from the day-to-day running of the NHS. But the 2021-22 Health and Care Bill has created some anxiety about a possible attempt by ministers to take more direct control of running the health service. Shortly before his departure, Matt Hancock, then secretary of state for health and social care, said that the legislation would give him the power to sign off on senior appointments to local NHS boards. ${ }^{1}$ At the same time, in other parts of the public sector, we have seen interest in appointing politically connected people to board positions at institutions like the BBC and Ofcom.

Now Hancock's successor, Sajid Javid, begins his time at the Department of Health with a bill that gives politicians powers to control the detail of how the health service is run. An insider recently told me how unsurprising it should be that the government should seek to exert such influence. "Why shouldn't we seek to appoint Conservatives to positions?” they asked. In this example they weren't referring to the NHS, however, even if off-the-record briefings have suggested that Simon Stevens, outgoing chief executive of NHS England, was not always compliant with government demands. ${ }^{3}$ That Stevens appeared to be more politically skilled than some senior politicians might also have proved irksome.

It is worth noting that Labour had a similar view on favourable appointments in the 200os, so this approach is nothing new. Javid's advisers should, however, present him with the risks of such an approach and explain why it may not deliver what politicians expect.

The most obvious point is that large, complex organisations require the best people. Whichever party might be in power, the size of its membership means that the talent pool for recruitment would be constrained. Appointing people from a wider group known to be sympathetic might get around this problem-but fails to avoid other problems that are more fundamental.

There is a strong argument for more diversity in the leadership of NHS organisations. This is associated with improved organisational performance and innovation. NHS England has made the case strongly, including the important point that it is not reasonable for the boards of NHS organisations to look very different from the population they serve or the staff that work in them.

Mixing political and managerial control can create confusion about where and how decisions are taken.
It creates a risk that different messages are transmitted down different routes and reduces transparency. It also cuts across some important principles of good governance. Those responsible for organisations have a key duty of stewardship of the organisation, safeguarding its long term future.

In countries where key health officials are politically appointed, I have observed a lack of willingness and an incentive to postpone anything contentious. As in the UK, hospitals often serve many constituencies, and there is the risk of important decisions being distorted by short term political considerations. NHS folklore already has it that there is only a two year window to make significant changes to local services before becoming entangled in politics.

The leaders of organisations also have an obligation to act as advocates for them and generally take their stewardship role seriously. This can lead to problems for politicians, who may find that the people they appointed because they were thought to be sympathetic to government policy have gone native and are now using their political skills to oppose it.

The well known case of the chair of Mersey Regional Health Authority in the 1980 ond 1990 s shows the risks of the feudal fiefdoms that can result from appointing those with a strong personal political power base. ${ }^{4}$ For many years, ministers and the Department of Health found that Mersey RHA interpreted policy in its own way and successfully resisted attempts to control it.

Where appointees do follow the party line, they risk losing credibility with staff and stakeholders by failing to advocate effectively for the organisation. It is unwise to create a culture of compliance in which there is no challenge, and this has been at the heart of many of the biggest errors made by governments over the years.

Introducing local politicians into elements of NHS governance is often helpful in ensuring that plans are locally sensitive and that links are made between different public sector plans. But that is very different from politicising key appointments within the system.

Political oversight of publicly funded institutions is legitimate and unavoidable. The machinery for accountability is already in place, and confusing political and managerial control is unwise, unnecessary, and potentially damaging.

Competing interests: none declared.

Commissioned, not peer reviewed among hospital directors to make difficult decisions, 
1 Brennan S. Government to take 'joint' role in appointing NHS chairs and CEOs. HSJ. 16 March 2021. www.hsj.co.uk/policy-and-regulation/government-to-take-joint-role-in-appointing-nhschairs-and-ceos/7029728.article.

2 Kuenssberg L. Paul Dacre and Ofcom: What's going on? BBC News. 28 May 2021. www.bbc.co.uk/news/uk-politics-57280438.

3 Simon Stevens to step down as NHS England boss at end of July. Guardian. 29 April 2021. www.theguardian.com/society/2021/apr/29/simon-stevens-to-step-down-as-nhs-england-bossat-end-of-july.

4 Lambert M, Begley P, Sheard S. Mersey Regional Health Authority, 1974-1994. Department of Public Health and Policy, University of Liverpool. www.liverpool.ac.uk/media/livacuk/iphs/2publichealthandpolicy/Mersey,RHA,WS,Transcript,Final,Version,September,2020.pdf. 